Available online:

http://journal.imla.or.id/index.php/arabi

IMLA Arabi : Journal of Arabic Studies, 4 (1), 2019, 100-114

DOI: http://dx.doi.org/10.24865/ajas.v4i1.107

\title{
PENGEMBANGAN BAHAN AJAR BAHASA ARAB BERBASIS TEORI BELAJAR KONSTRUKTIVISME UNTUK MAHASISWA
}

\author{
M. Abdul Hamid, Danial Hilmi, Syaiful Mustofa \\ Universitas Islam Negeri Maulana Malik Ibrahim Malang, Indonesia \\ E-mail : hamidlana@yahoo.com
}

\begin{abstract}
Teaching materials are very important in the process of learning Arabic; therefore, the teaching and learning process requires motivation to increase student language competence. With regard to the material taught in higher education, the urgency of constructivism theory has not yet fulfilled in the success of learning. As a result, the theory becomes a necessity for the development of teaching material to strengthen their interest in developing language competencies. This study intended to develop Arabic teaching materials for students in Islamic Religious Colleges so that they do not depend on books sourced from Arab countries that have different cultures than local cultures. Based on the results of the needs analysis, the textbook product was produced, which is named al-Arabia li al-Hayah along with inputs from experts. The results of this book trial showed that this book was effective to meet the needs of students in improving Arabic competence through mastery of vocabulary in their environment.
\end{abstract}

Keywords: development of teaching materials, Arabic language, behaviorism

\section{Abstrak}

Bahan ajar sangat penting dalam proses pembelajaran bahasa Arab. Oleh karena itu, proses belajar mengajar memerlukan dorongan motivasi dalam rangka peningkatan kompetensi kebahasaan mahasiswa. Berkenaan dengan materi yang diajarkan di perguruan tinggi belum memenuhi urgensi teori konstruktivisme dalam keberhasilan belajar, maka teori tersebut menjadi keharusan pengembangan materi ajar sehingga akan memperkuat minat mereka dalam mengembangkan kompetensi bahasanya. Penelitian ini bermaksud mengembangkan materi ajar bahasa Arab bagi mahasiswa di Perguruan Tinggi Keagamaan Islam sehingga tidak bergantung pada buku-buku yang bersumber dari negara-negara Arab yang mengandung budaya berbeda dengan budaya lokal. Buku al-Arabiyyah li al-Hayah merupakan produk buku ajar yang dihasilkan melalui hasil analisis kebutuhan dan masukan-masukan dari para ahli. Sedangkan hasil uji coba buku ini menunjukkan bahwa buku ini efektif untuk memenuhi kebutuhan mahasiswa dalam meningkatkan kompetensi bahasa Arab melalui penguasaan kosakata yang ada di lingkungan mereka.

Kata Kunci: pengembangan bahan ajar, bahasa Arab, behaviorisme 


\section{Pendahuluan}

Dalam menjalankan proses pembelajaran, diperlukan adanya bahan ajar yang merupakan komponen penting dalam sebuah proses belajar mengajar. Untuk mewujudkannya seorang dosen dan mahasiswa harus bahu membahu dalam melaksanakan pengajaran yang tersaji melalui sebuah bahan ajar. Sehingga dengan demikian dosen tidak hanya terpaku pada suasana di dalam kelas, namun menjadi penentu keberhasilan belajar mengajar. Selain itu, bahan ajar dapat berupa serangkaian materi yang disajikan secara sistematis, namun juga diperlukan pendayagunaan pikiran demi tercapainya pendidikan yang berkualitas.

Bahan ajar sebagai media dan sumber informasi dalam pembelajaran sangat penting artinya dalam menambah dan meningkatkan efektivitas pembelajaran. Bermanfaat tidaknya suatu bahan ajar dalam proses pembelajaran sangat tergantung pada kemampuan guru dalam mengembangkan dan memanfaatkannya, sehingga langkah-langkah pengembangan bahan ajar yang baik dan memenuhi syarat perlu dikuasai. Selian itu, guru juga dituntut untuk mengetahui dan menguasai macam-macam bahan ajar, kegunaan bahan ajar, dan pengorganisasiannya.

Bahan ajar menduduki posisi yang penting dalam proses pembelajaran baik bagi dosen maupun mahasiswa. Dosen akan mengalami kesulitan dalam meningkatkan efektivitas pembelajaran tanpa adanya bahan ajar. Begitu pula halnya mahasiswa, tanpa bahan ajar akan menemui hambatan untuk menyesuaikan diri dalam pembelajaran, apalagi jika dosen menyampaikan dan mengemukakan materi dengan cepat dan kurang jelas. Mahasiswa dapat kehilangan arah dan jejak, sehingga tidak mampu mencerna dan menelusuri kembali apa yang telah diajarkan oleh dosen. Oleh karena itu, bahan ajar merupakan bahan yang dapat digunakan dan dimanfaatkan oleh dosenmaupun mahasiswa sebagai salah satu usaha untuk membenahi dan memperbaiki mutu pembelajaran.

Beberapa penelitian atau pemikiran yang terkait dengan pentingnya bahan ajar yang mempertimbangkan teori belajar behaviorisme sebagaimana berikut ini; (1) Inthishar Ghazi Musthofa (2016), Mumarasat at-Ta'allum al-Binai Lada Muallim at-Tarbiyah al-Islamiyah wa 'Alaqatuha bi ba'dhi al-Mutaghayyirat, (2) Sahkholid Nasution dan Zulheddi (2018), Pengembangan Model Pembelajaran Bahasa Arab Berbasis Teori Konstruktivisme di Perguruan Tinggi, (3) Ahmet Gursesa, Seher Demiraya, Cetin Doğar (2015), A Design Practice For Interactive-Direct Teaching Based On Constructivist Learning: Dissolution And Solutions, (4) Prabowo Adi Widayat (2017), Inovasi Kurikulum Bahasa Arab Madrasah Aliyah Berbasis Konstruktivisme, dan (5) Danu Aji Nugraha, Achmad Binadja, Supartono (2013), Pengembangan Bahan Ajar Reaksi Redoks Bervisi Sets, Berorientasi Konstruktivistik.

Penelitian sebagaimana dijelaskan di atas, mengarahkan kepada bagaimana pentingnya teori belajar konstruksivisme dan bahan ajar bahasa Arab sebagai salah satu komponen dalam pembelajaran bahasa Arab. Sementara penelitian ini lebih mengarahkan kepada bagaimana pemecahan masalah pembelajaran bahasa Arab di PTKIN yang mengharuskan memiliki buku ajar secara mandiri dikarenakan buku yang diperoleh dari Arab terkadang tidak sesuai dengan budaya mahasiswa Indonesia, sehingga tujuan pembelajaran tidak terarah. Dengan demikian, penelitian ini bermaksud mengembangkan bahan ajar bahasa Arab yang mengedepankan teori belajar konstruktivisme untuk memecahkan persoalan materi bahasa Arab di PTKIN.

Berdasarkan pentingnya kedudukan bahan ajar dalam proses belajar-mengajar, maka peneliti melakukan pengamatan dan penelusuran di beberapa lembaga pendidikan tentang materi pembelajaran bahan Arab. Dari hasil pengamatan peneliti, ditemukan bahwa materi pembelajaran bahasa Arab di lembaga-lembaga pendidikan di Indonesia secara umum dan di Perguruan Tinggi secara khusus, lebih banyak disusun berdasarkan pada pengetahuan dan pengalaman yang dimiliki dan masih belum didasarkan pada hasil analisis kebutuhan para peserta didik. Hal ini mengakibatkan program pembelajaran bahasa Arab dimungkinkan belum memenuhi tujuan dan karakteristik kebutuhan peserta didik. 


\section{Arabi : Journal of Arabic Studies}

Selain itu, buku tersebut masih belum sesuai dengan kondisi dan kebutuhan para mahasiswa secara nyata. Hal ini dikarenakan buku yang digunakan memang tidak secara khusus dikembangkan untuk digunakan di Perguruan Tinggi dengan karakteristik yang sesuai dengan tingkat kebutuhan para mahasiswa. Apalagi bahan ajar yang berupa buku tersebut merupakan hasil karya penutur asli yang memiliki perbedaan sosial, budaya, dan tradisi.

Bahan ajar baik bahan ajar cetak seperti buku, lembar kerja siswa, handout, maupun bahanbahan non cetak tentang bahasa Arab masih dirasa sangat kurang sekali dari segi jumlah dan sulit didapatkan di Indonesia. Kebanyakan bahan ajar masih menggunakan metode seadanya dan kurang memperhatikan kesesuaian kontek sosial budaya dan pendekatan pembelajaran.

Berdasarkan beberapa hal tersebut di atas, maka perlu dikembangkan produk pembelajaran bahasa Arab yang dapat meningkatkan efektivitas dan efisiensi pembelajaran. Adapun hasil pengembangan yang memenuhi harapan tersebut adalah pengembangan materi yang disusun berdasarkan prinsip-prinsip pembelajaran yang mempunyai ciri-ciri: a) meningkatkan gairah membaca buku, b) perancangan bahan ajar dalam menunjang dan mengarahkan kegiatan santri, c) penjelasan tujuan pembelajaran, d) penyusunan berdasarkan pola belajar yang fleksibel, e) struktur bahan ajar disusun berdasarkan kurikulum yang berlaku dan kompetensi akhir yang hendak dipenuhi, f) berorientasi pada adanya kesempatan bagi santri untuk mengasah kemampuannya, g) mengakomodasikan kesulitan belajar santri, h) terdapat ringkasan, i) gaya penulisan (bahasanya) komunikatif, j) kepadatan berdasarkan kebutuhan santri, k) dikemas untuk digunakan dalam proses pembelajaran, 1) mempunyai mekanisme untuk mengumpulkan umpan balik dari santri, dan m) menjelaskan cara mempelajari buku ajar (Lewis dan Paine, dalam Hakim: 1999).

Pengembangan bahan ajar memerlukan alasan logis dan sistematis yang menunjang ketercapaian proses belajar mengajar. Adapun alasan utama dilakukan kajian dan pengembangan buku ajar di PTKIN adalah sebagai berikut: a) penyusunan materi bahasa Arab di lingkungan PTKIN belum sepenuhnya didasarkan pada hasil analisis kebutuhan mahasiswa, b) materi pembelajaran yang ada masih merupakan karya dari luar, c) perlunya PTKIN memiliki karya sendiri yang sesuai dengan kondisi sosial, budaya, dan kemampuan mahasiswa di Indonesia.

Adapun rumusan masalah dalam penelitian ini yaitu; 1) bagaimana bentuk bahan ajar bahasa Arab untuk mahasiswa di lingkungan PTKIN yang bisa membantu proses pembelajaran bahasa Arab dengan mudah dan menyenangkan berbasis teori belajar konstruktivisme? 2) bagaimana efektivitas bahan ajar bahasa Arab yang dikembangkan untuk mahasiswa di lingkungan PTKIN yang bisa membantu proses pembelajaran bahasa Arab yang mudah dan menyenangkan berbasis teori belajar konstruktivisme?

Sebagaimana keterangan dalam rumusan masalah, maka tujuan penelitian ini di antaranya; 1) mengembangkan produk bahan ajar bahasa Arab untuk mahasiswa di lingkungan PTKIN yang bisa membantu proses pembelajaran bahasa Arab dengan mudah dan menyenangkan berbasis teori belajar konstruktivisme, dan 2) mengukur efektivitas bahasa ajar bahasa Arab yang dikembangkan untuk mahasiswa di lingkungan PTKIN yang bisa membantu proses pembelajaran bahasa Arab dengan mudah dan menyenangkan berbasis teori belajar konstruktivisme.

\section{Konsep Pembelajaran Konstruktivisme}

Pembelajaran konstruktivisme merupakan salah satu pembelajaran yang memperhatikan bagaimana konsep itu dibentuk oleh peserta didik dengan menggunakan kemampuan menalar dan mempertemukan antar komponen yang dapat diukur dan diketahui secara relatif dalam mendalami pengetahuan yang sebenarnya. Konstruktivisme membutuhkan kreatifitas guru dan kesiapan peserta didik untuk membentuk konsep yang sesuai dengan tujuan yang diharapkan.

Di era modern, peran guru tidak hanya sebatas mentransfer ilmu pengetahuan, melainkan sebagai fasilitator yang membantu peningkatan peserta didik dalam keilmuan. Fasilitasi yang diberikan kepada peserta didik dapat berupa pemenuhan keadaan yang dapat mengkonstruksi pengetahuan secara tepat dan efektif guna tercapainya tujuan pembelajaran yang diharapkan.

Vol. 4 No. 1 | 102-114

Copyright (C) 2019 | ARABI | p-ISSN 2548-6616 | e-ISSN 2548-6624 
(Hudoyo, 1998: 5-6). Teori pembelajaran konstruktivisme mengharuskan untuk belajar di lingkungan nyata dan perlunya adanya upaya untuk menarik kepada pengalaman siswa sehari-hari. Kebanyakan pembelajaran tradisional lebih mengedepankan pengetahuan struktural dan mengabaikan pola yang dibangun secara mandiri. Selain itu, pembangunan pengetahuan baru harus digali untuk dapatnya siswa menemukan sendiri jalan keluar yang sesuai dengan pemecahan masalah yang juga dialami sendiri (Jia, 2010: 199).

Penerapan belajar konstruktivisme diperlukan fasilitasi guru untuk memvalidasi pengetahuan agar tidak keluar dari jalur yang relevan. Selain itu, pengalaman peserta didik sangat diperhitungkan dalam setiap kegiatan yang tersaji dalam sebuah pembelajaran di dalam kelas. Menurut Mvududu (2012: 109) pandangan konstruktivistik kerap disebut sebagai konsep utama dalam sebuah teori belajar. Banyak kalangan menganggap bahwa teori belajar yang memiliki makna pencarian pengetahuan melalui proses pedagogis juga menggunakan paradigma konstruktivistik yang memandang secara menyeluruh tentang sains dan lainnya.

Bertambahnya pengalaman dan interaksi dengan lingkungan menurut kaum konstruktivis di luar kelas merupakan bagian mengkonstruksi diri di mana seseorang dapat belajar dari pengalaman dirinya dan pengalaman orang lain. Pengalaman yang didapat oleh peserta didik di luar kelas akan tercatat dan terbangun dalam bentuk gagasan-gagasan dan tanggapan-tanggapan. Gagasan dan tanggapan ini akan tertuang dalam kata-kata yang disampaikan kepada orang yang mendengarkan ceritanya (Yamin, 2011: 3).

Pengalaman itu akan menciptakan gagasan dan tanggapan yang bersifat mental, di mana dapat menghadirkan sesuatu yang tidak tampak, cerita itu akan menciptakan komunikasi dua arah, seolah-olah ia ikut merasakan, melihat, mengamati, dan menikmati secara mental. Kemampuan kognitif manusia dapat menghadirkan realitas dunia ke dalam dirinya, mulai dari hal-hal yang bersifat material dan non material, seperti memperagakan perilaku seekor binatang yang cerdik dengan suasana penonton yang gembira. Oleh sebab itu, semakin banyak tanggapan dan gagasan yang dimiliki seseorang, semakin kaya dan luaslah pengetahuan orang itu. Konstruksi pengetahuan itu harus dikembangkan melalui belajar (Yamin, 2011: 3-4).

Dalam sebuah proses pembelajaran, kemampuan untuk mengkonstruk dari apa yang telah diperoleh di kelas menjadi tuntutan yang harus dilakukan oleh peserta didik. konstruksi pengetahuan tidak akan diperoleh jika optimalisasi daya berfikir tidak dilaksanakan untuk mengamati fenomena yang terjadi di sekeliling peserta didik. Menurut Mills (2006: 28) terdapat beberapa kunci perbedaan antara penelitian ataupun kajian dari sebuah teori grounded berevolusi dan pendekatan teori grounded tradisional. Saat ini bahasan tentang karakteristik umum teori grounded theory yang terangkum dalam bentuk pengkodean dan lain-lain digunakan untuk melihat pendekatan konstruktivis yang sering digaungkan oleh Strauss dan Corbin.

Pembelajaran berbasis Konstruktivisme berangkat dari konsep filsafat di mana eksistensi manusia merupakan makhluk yang berfikir secara logis harus mendayagunakan akal yang dimiliki. Oleh karena itu, pembelajaran konstruktivisme tentunya hipotesis yang mempertemukan antara satu variabel dengan variabel lain. Selanjutnya, konstruktivistik berlandaskan pada dua hipotesis sebagai berikut (Yamin, 2011: 8):

a. Pengetahuan yang dimiliki oleh seseorang merupakan hasil yang dibangun (dikonstruksi) secara aktif oleh dan dalam diri subyek belajar; bukan secara pasif diterima dari lingkungan belajarnya.

b. Peranjakan dalam memahami pengetahuan (menjadi tahu) tentang sesuatu merupakan proses adaptif (penyesuaian) yang dilakukan seseorang dalam mengorganisasikan pengalaman pebelajar (orang tersebut) dalam interaksinya dengan lingkungannya, bukan menemukan sesuatu di luar diri orang tersebut.

Prinsip pembelajaran konstruktivisme berpegangan pada pendayagunaan pikiran untuk secara aktif menghimpun dan membangun pengetahuan yang dicerna dalam pikirannya. Selain itu, pengetahuan tidak dapat diterima secara sempurna jika hanya pasif menerima dari lingkungan 


\section{Arabi : Journal of Arabic Studies}

belajar. Oleh karena itu, peserta didik harus aktif baik itu dengan cara bertanya, mengamati secara aktif maupun melacak dan menyusun sebagaimana apa yang telah diperoleh di dalam dan atau di luar kelas.

Untuk melaksanakan proses pengembangan belajar berbasis konstruktivisme, maka diperlukan penekanan pada prinsip-prinsip yang berdasar kemampuan untuk menata sendiri di kalangan peserta didik. Adapun prinsip-prinsip dasar pembelajaran konstruktivisme di antaranya (Yamin, 2011: 15): pembangunan interpretasi terhadap dunia nyata berdasarkan pengetahuan baru yang dilakukan melalui interaksi sosial, pengalaman diperoleh melalui pembangunan konsep senyatanya, pemerolehan didapatkan secara dinamis tanpa melakukan pemaksaan yang tidak tepat, berbagai cara dilakukan untuk membentuk pengetahuan yang cukup dan variatif dengan cara bagaimana melihat dunia sekitar serta perlunya setiap individu memahami realitas yang terjadi di setiap sisi kehidupan nyata.

Pembangunan konsep melalui pengalaman baru merupakan suatu keharusan yang harus ditekankan oleh pengajar. Pengalaman tersebut dapat diperoleh melalui interaksi sosial dengan masyarakat sekolah dan lingkungan sekitar dalam rangka mempertemukan antara konsep yang telah diajarkan dengan kondisi sosial masyarakat sekitar. Integrasi pengalaman dan konsep yang dimiliki akan dapat meningkatkan pemahaman pada suatu fenomena tertentu yang membutuhkan penalaran secara utuh dan lengkap.

Pembangunan konsep yang membentuk sebuah informasi, pengetahuan, dan pemahaman secara teoritis dapat dicarikan titik temu, namun dalam tataran praktis sepertinya sulit untuk diterapkan karena banyak unsur-unsur pembentuk yang berseberangan dan tumpang tindih antara satu dengan lainnya. Di samping itu, pembelajaran kognitif lebih menitikberatkan pada hal mendasar terutama bagi pendidikan, sehingga tanggapan secara afektif juga perlu diperhitungkan (Scoffham, 2018: 137).

Berkaitan dengan konsep belajar konstruktivisme, maka tidak dapat dilepaskan dengan model pembelajaran. Adapun model pembelajaran merupakan sebuah perangkat yang dapat digunakan untuk melakukan perubahan secara perlahan maupun cepat. Dalam sebuah model, pembelajar berperan sebagai kaum terpelajar yang memiliki kompetensi dalam menjalan tugas dan fungsinya agar terbentuknya metodologi pembelajaran yang bersifat tidak tetap sehingga menuntut seorang guru untuk memiliki inovasi dalam mengembangkan pembelajaran, memikirkan perubahan yang ada pada diri peserta didik, serta melakukan perubahan terhadap pandangan lama menuju pandangan baru yang relevan (Yamin, 2011: 1).

Model perubahan konseptual yang paling berpengaruh memberikan asumsi bahwa setiap siswa datang menuju sekolah atau tempat belajar dengan membawa bentuk kesalahpahaman terkait dengan fenomena alam yang menyatakan bahwa kesalahpahaman tersebut perlu dimunculkan, ditantang dengan menunjukkan contoh-contoh yang saling bertentangan untuk ditanggapi melalui konsep umum yang akan diterima siswa (Cakir, 2008: 198). Dengan demikian pembelajaran konstruktivisme akan memberikan pemahaman kepada siswa setelah pandangan umum secara mandiri dialami sendiri oleh siswa melalui kerja kognitif.

Pengembangan bahan ajar membutuhkan upaya yang sistematis dan terarah untuk terwujudnya sebuah produk buku yang relevan dan efektif digunakan dalam pembelajaran. Terutama dalam meningkatkan proses belajar mengajar, maka guru harus mengedepankan model belajar berbasis konstruktivisme (Sholihah, 2013: 6).

Bahan ajar yang mencerminkan konsep teori belajar konstruktivisme tidak berorientasi pada penyampaian tujuan dan materi pembelajaran secara langsung, namun meminta kepada peserta didik untuk melakukan pengamatan dan analisis sosial tentang apa yang diperoleh dari sebuah bangunan materi untuk dikenali dan disusun secara mandiri oleh peserta didik itu sendiri.

Pembelajaran yang berorientasi pada konsep konstruktivisme mengajak peserta didik perlu dilakukan interaksi dan kerja sama antar komponen baik antar peserta didik, masyarakat maupun lingkungan belajar. Hal ini bertujuan untuk mengasah kemampuan mereka dalam memahami dan

Vol. 4 No. 1 | 104-114

Copyright @ 2019 | ARABI | p-ISSN 2548-6616 | e-ISSN 2548-6624 
memaknai apa yang ditemui di lapangan. Sebagai bentuk akhir dari pembentukan konsep oleh peserta didik, maka guru atau pengajar menyusun perencanaan dan materi yang mewujudkan sisi pembentukan konsep yang harus dipupuk oleh segenap peserta didik untuk tercapainya pemahaman yang menyeluruh.

\section{Konsep Pengembangan Bahan Ajar Bahasa Arab}

Bahan Ajar menurut Pannen (1995) merupakan seperangkat bahan-bahan yang disiapkan dan disusun secara obyektif dan sistematis yang dipergunakan baik oleh guru maupun siswa dalam upaya untuk menjalankan proses pembelajaran yang efektif. Sementara itu, Sadjati (2003: 3) mengatakan bahwa bahan ajar bersifat unik dan spesifik yang hanya dipergunakan untuk pembelajar di dalam kelas maupun di luar kelas yang bertujuan untuk mencapai tujuan pembelajarannya. Di satu sisi, spesifik bermaksud bahwa penyusunan bahan ajar harus detail dan rinci yang relevan untuk keperluan ketercapaian tujuan tersebut.

Terkait Materi pembelajaran, Kemp (1977: 44) menjelaskan bahwa bahan ajar berisi gabungan antara pengetahuan dalam bentuk fakta dan informasi terperinci, kumpulan keterampilan yang berisi langkah-langkah, prosedur serta faktor sikap yang dapat memberi keterangan yang komplit terhadap apa saja yang dibutuhkan oleh siswa. Di satu sisi, Merril (1977: 37) menuturkan bahwa terdapat perbedaan isi materi pelajaran yang berisi empat hal di antaranya: fakta, konsep, prosedur, dan prinsip.

Bahan ajar bahasa Arab adalah materi pelajaran bahasa Arab yang merupakan gabungan antara pengetahuan, ketrampilan, dan faktor sikap, yang disusun secara sistematis sehingga dapat digunakan guru dan siswa dalam proses pembelajaran bahasa Arab. Dengan demikian tidak semua buku yang dapat ditemukan dalam berbagai literatur disebut bahan ajar.

Berdasarkan hal tersebut, buku ajar dapat berupa bahan cetak atau non cetak, visual maupun audio yang berisi materi pembelajaran yang memang difungsikan untuk menunjang proses pembelajaran yang disusun secara sistematis untuk keperluan belajar mengajar. Buku yang tidak disusun dengan memuat materi yang harus dikuasai oleh peserta didik, tidak dapat dikatakan sebagai bahan ajar. Begitu juga buku yang tertuang di dalamnya materi yang harus dikuasai tetapi tidak tertulis di dalamnya prosedur sistematis yang dengan melibatkan komponen pembelajaran utama, penunjang, dan evaluasi walaupun itu buku karya ulama terdahulu yang banyak dikaji di berbagai pondok pesantren, tidak dapat dikatakan bahan ajar.

Sedangkan pentingnya bahan ajar dalam proses belajar-mengajar sudah dapat dipastikan sangat penting. Bahan ajar menduduki posisi yang penting dalam proses pembelajaran baik bagi guru maupun siswa. Guru akan mengalami kesulitan dalam meningkatkan efektivitas pembelajaran tanpa adanya bahan ajar. Begitu pula halnya siswa, tanpa bahan ajar akan menemui hambatan untuk menyesuaikan diri dalam pembelajaran, apalagi jika guru menyampaikan dan mengemukakan materi dengan cepat dan kurang jelas. Murid dapat kehilangan arah dan jejak, sehingga tidak mampu mencerna dan menelusuri kembali apa yang telah diajarkan oleh guru. Oleh karena itu, bahan ajar merupakan bahan yang dapat digunakan dan dimanfaatkan oleh guru maupun siswa sebagai salah satu usaha untuk membenahi dan memperbaiki mutu pembelajaran. Bahan ajar selain harus dirancang secara sistematis, juga harus dilengkapi dengan komponenkomponen yang dapat menunjang proses belajar-mengajar sehingga dapat mengantarkan peserta didik kepada tujuan yang telah ditetapkan.

Komponen bahan ajar menurut Pannen (1994) terdiri dari tiga komponen inti, yaitu komponen utama, komponen pelengkap, dan komponen evaluasi hasil belajar. Komponen utama berisi informasi atau topik utama yang ingin disampaikan kepada siswa, atau harus dikuasai siswa. Umumnya bahan ajar utama berbentuk bahan ajar cetak. Sedangkan komponen pelengkap dapat berupa informasi atau topik tambahan yang terintegrasi dengan bahan ajar utama, atau informasi atau topik pengayaan wawasan siswa. Biasanya komponen pelengkap terdiri dari bahan pendukung cetak (materi pengayaan, bacaan, jadwal, silabus), bahan pendukung non cetak (kaset, CD, VCD), 


\section{Arabi : Journal of Arabic Studies}

panduan siswa, panduan guru, dan lain-lain yang diperlukan siswa untuk mempelajari suatu topik yang disajikan melalui beragam media. Adapun komponen evaluasi hasil belajar terdiri dari perangkat soal atau butir tes atau alat evaluasi hasil belajar non tes yang dapat digunakan untuk tes formatif siswa selama proses pembelajaran Bahasa Arab dan tes sumatif siswa pada akhir semester.

Selanjutnya beberapa ahli, seperti Dick dan Carey (1990), Degeng (1990, 1997), Tarigan (1990), dan Suparman (1994), menjelaskan pedoman pengembangan buku ajar adalah terpenuhinya komponen-komponen bahan ajar yang relevan dengan kebutuhan proses belajar-mengajar, seperti adanya 1) petunjuk penggunaan buku ajar, 2) tujuan umum dan tujuan khusus pembelajar, 3) epitome (kerangka isi), 4) urain isi bahan pembelajaran, 5) gambar/illustrasi, 6) rangkuman, 7) soal latihan, kunci jawaban, balikan, dan 8) tugas-tugas. Komponen-komponen buku ajar tersebut digunakan dalam menyusun penulisan buku ajar.

Tahapan-tahapan dalam pengembangan bahan ajar, memerlukan pengujian kelayakan yang dilakukan oleh pakar yang dalam hal ini diwujudkan dalam bentuk validasi mendalam secara profesional untuk selanjutnya dilakukan revisi sebagai persiapan dalam proses pembelajaran. Pada saat dilakukan proses pembelajaran, maka perlu dilakukan observasi terintegrasi dengan karakter kerjasama, menghargai pendapat orang lain dan penetapan disiplin diri. Sebagai tindak lanjut dan untuk mengetahui hasil akhir, maka diperlukan pemberlakukan tes untuk mengetahui peningkatan prestasi belajar siswa (Buchori, 2015: 384).

Dari penjelasan di atas, nampaknya memang dalam membuat buku ajar Bahasa Arab tidaklah semudah yang dibayangkan, di pasaran telah banyak kita temukan buku ajar Bahasa Arab, tetapi tidak semuanya memiliki komponen atau unsur-unsur buku ajar yang telah disebutkan di atas.

\section{Metode Penelitian}

Metode yang dipergunakan dalam penelitian ini adalah penelitian pengembangan yang tercermin melalui jenis penelitian Research and Development. Hal ini dikarenakan dalam memecahkan persoalan di tingkat Perguruan Tinggi Keagamaan Islam Negeri (PTKIN), khususnya belum optimalnya kemampuan mahasiswa ataupun lulusan dalam memiliki kompetensi yang ideal di mana bahasa Arab menjadi hal yang tidak bisa tidak harus dikuasai sebagai bahan untuk dapat melakukan kajian keagamaan Islam melalui penelusuran mandiri kitab peninggalan ulama terdahulu.

Model rancangan pembelajaran yang digunakan dalam pengembangan ini adalah model yang dikemukakan oleh Dick dan Carey (1990), dengan langkah-langkah sebagai berikut: 1) mengidentifikasi tujuan pembelajaran, 2) melakukan analisis pembelajaran, 3) mengidentifikasi prilaku masukan dan karakteristik pembelajar, 4) merumuskan tujuan pembelajaran dan kompetensi, 5) mengembangkan butir-butir tes, 6) mengembangkan strategi pembelajaran, 7) mengembangkan materi pembelajaran, 8) merancang dan melaksanakan evaluasi, dan 9) merevisi bahan pembelajaran.

Adapun data dan sumber data yang digunakan dalam penelitian ini adalah keterangan dan informasi tentang pembelajaran bahasa Arab di PTKIN, kemampuan mahasiswa dalam materi bahasa Arab serta hasil penyebaran kuisioner yang dapat menggali data yang dari mahasiswa. Demikian juga data diperoleh dari hasil penilaian produk yang dilakukan oleh tim ahli sebagai rangkaian akhir sebelum produk tersebut diujicobakan untuk mendapatkan masukan dan perbaikan serta diketahui kelayakan yang standar. Adapun tahapan yang dilakukan dalam penelitian ini diantaranya perancangan, disain dan uji coba produk. Sementara teknik pengumpulan data yang dipergunakan yaitu wawancara, observasi dan penyebaran angket untuk mengetahui tingkat efektifitas penggunaan buku ajar sebagai bagian dari proses pengembangan.

\section{Hasil Penelitian dan Pembahasan}

\section{Pengembangan Buku Bahasa Arab Berbasis Teori Belajar Konstruktivisme}


Buku Bahasa Arab berbasis teori konstruktivisme yang dikembangkan dalam penelitian ini diberi nama al Arabiyah lil Hayah disingkat ALH. Buku ini dikembangkan melalui analisis kebutuhan yang dilakukan peneliti terhadap mahasiswa Universitas Islam Negeri Maulana Malik Ibrahim Malang di Program Khusus Perkuliahan Bahasa Arab (PKPBA).

ALH dirancang berdasarkan teori belajar konstruktivisme yang menekankan pada proses belajar, mendorong peserta didik untuk berpartisipasi aktif dalam dialog atau diskusi dengan peserta didik lain dan guru, melibatkan peserta didik dalam situasi dunia nyata, menekankan pentingnya konteks dalam belajar, dan memberikan kesempatan kepada peserta didik untuk membangung pengetahuan dan pemahaman baru yang didasarkan pada pengalaman nyata.

Buku ini sangat tepat untuk mereka para mahasiswa di Lingkungan Perguruan Tinggi Keagamaan Islam (PTKIN), yaitu UIN/IAIN/STAIN, juga PTKI Swasta, karena dirancang berdasarkan analisis kebutuhan dan pengalaman mengembangkan pembelajaran bahasa Arab di UIN Maulana Malik Ibrahim Malang selama 20 tahun dan memperhatikan kondisi sosial-budaya para pembelajar.

Tujuan utama pembelajaran bahasa Arab "al-Arabiyah lil Hayah" adalah membekali mahasiswa kemampuan berbahasa Arab fushha secara aktif; baik lisan maupun tulisan, yang dapat mereka gunakan untuk berkomunikasi dasar dengan penutur dalam berbagai konteks, dan selanjutnya mampu mengkaji studi Islam (tafsir, hadits, fiqh, tasawwuf, sejarah Islam) di Fakultas dan Jurusan/Prodi di Lingkungan PTKIN juga PTKI.

Buku ALH terdiri dari delapan wihdah (unit); setiap unit terdari dari al hiwar, al mufrodat, al tarakib, al istima', al kalam, al qira'ah, dan al kitabah. Pada setiap komponen tersebut dilengkapi dengan latihan-latihan yang dapat membantu mahasiswa dalam penguasaan capaian hasil yang telah ditetapkan.

Setiap komponen materi di atas dirancang dan disusun untuk mencapai hasil belajar atau kompetensi tertentu dalam penguasaan bahasa Arab. Berikut ini capaian hasil belajar yang telah dirumuskan.

Tabel 1: Capaian Hasil Belajar Mufradāt, Tarākìb, dan Istimā',

\begin{tabular}{|c|c|c|c|c|}
\hline \multirow{2}{*}{ Unit } & \multirow{2}{*}{ Judul } & \multicolumn{3}{|c|}{ Capaian Hasil Belajar } \\
\hline & & Mufrodat & Tarakib & Istima \\
\hline 1 & تعارف & $\begin{array}{l}\text { Mampu: } \\
\text { 1. Melafalkan kosakata } \\
\text { Arab tentang ta'arruf, } \\
\text { 2. Mengetahui arti } \\
\text { kosakata Arab tentang } \\
\text { ta'âruf. } \\
\text { 3. Menyebutkan } \\
\text { bilangan 1-10 }\end{array}$ & $\begin{array}{l}\text { Mampu: } \\
\text { 1. Menggunakan kata } \\
\text { tanya ما، كيف، أين، هل، كيف، أين، هل } \text {. } \\
\text { 2. Menjawab } \\
\text { pertanyaan dengan kata } \\
\text { tanya } \\
\text { 3. Menggunakan Ya } \\
\text { nisbah dalam konteks } \\
\text { identitas }\end{array}$ & $\begin{array}{l}\text { Mampu: } \\
\text { 1. Mengidentifikasi bunyi } \\
\text { hurufyang berdekatan } \\
\text { makhrajnya dalam kata, } \\
(\text { (أ-ֹ) }) \\
\text { 2. Mengidentifikasi bunyi } \\
\text { huruf yang panjang, pendek, } \\
\text { dan bertasydid dalam kata, } \\
\text { 3. Mengidentifikasi bunyi } \\
\text { kata yang didengar. }\end{array}$ \\
\hline 2 & الأسرة & $\begin{array}{l}\text { Mampu: } \\
\text { 1. Melafalkan kosakata } \\
\text { Arab tentang usrah, } \\
\text { 2. Mengetahui arti kosa } \\
\text { kata Arab tentang }\end{array}$ & 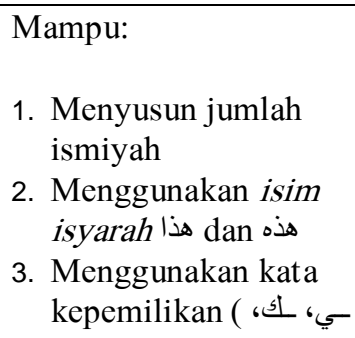 & 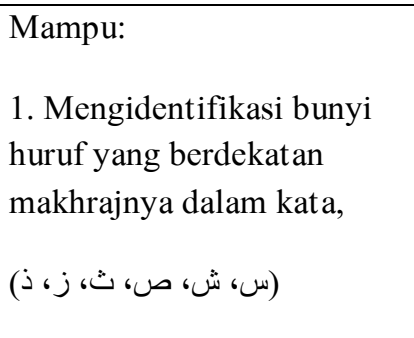 \\
\hline
\end{tabular}




\begin{tabular}{|c|c|c|c|c|}
\hline & & $\begin{array}{l}\text { usrah. } \\
\text { 3. Menyebutkan } \\
\text { bilangan 11-20 }\end{array}$ & (ه) (வ) & $\begin{array}{l}\text { 2. Mengidentifikasi bunyi } \\
\text { huruf yang panjang, pendek, } \\
\text { dan bertasydid dalam kata, } \\
\text { 3. Mengidentifikasi bunyi } \\
\text { kata yang didengar. }\end{array}$ \\
\hline 3 & السكن & $\begin{array}{l}\text { Mampu: } \\
\text { 1. Melafalkan kosa kata } \\
\text { Arab tentang usrah, } \\
\text { 2. Mengetahui arti kosa } \\
\text { kata Arab tentang } \\
\text { usrah. } \\
\text { 3. Mengetahui kosa } \\
\text { kata tentang dhorf } \\
\text { makan. } \\
4 . \text { Menyebutkan } \\
\text { bilangan bertingkat 1- } \\
10\end{array}$ & 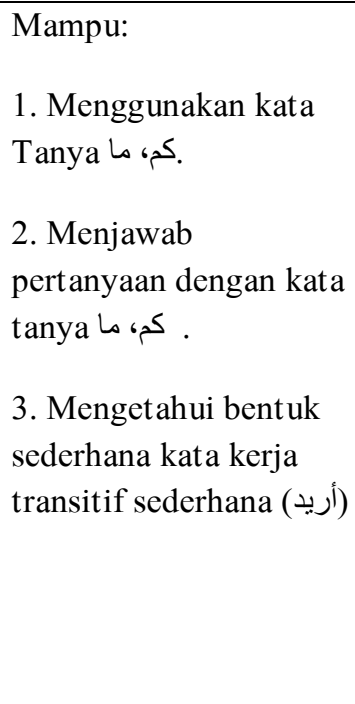 & $\begin{array}{l}\text { Mampu: } \\
\text { 1. Mengidentifikasi bunyi } \\
\text { huruf yang berdekatan } \\
\text { makhrajnya dalam kata, } \\
\text { ) (ت، ط، ظ، ض. Mengidentifikasi bunyi } \\
\text { huruf yang panjang, pendek, } \\
\text { dan bertasydid dalam kata, } \\
\text { 3. Mengidentifikasi bunyi } \\
\text { dua kata yang didengar. }\end{array}$ \\
\hline 4 & اليومية & $\begin{array}{l}\text { Mampu: } \\
\text { 1. Mengetahui arti } \\
\text { kosakata Arab tentang } \\
\text { ansyitah yaumiyyah. } \\
\text { 2. Menyebutkan } \\
\text { bilangan bertingkat 11- } \\
20\end{array}$ & $\begin{array}{l}\text { Mampu: } \\
\begin{array}{l}\text { 1. Menggunakan kata } \\
\text { tanya sل أين، ماذا، }\end{array} \\
\text { 2. Menggunakan kata } \\
\text { ganti Anta, Ana, dan } \\
\text { Anti pada kata } \\
\text { kerja. } \\
\text { 3. Menggunakan huruf } \\
\text { Sin untuk } \\
\text { menyatakan } \\
\text { aktivitas yang akan } \\
\text { datang. } \\
\text { 4. Menggunakan angka } \\
\text { dalam menunjukkan } \\
\text { jam }\end{array}$ & 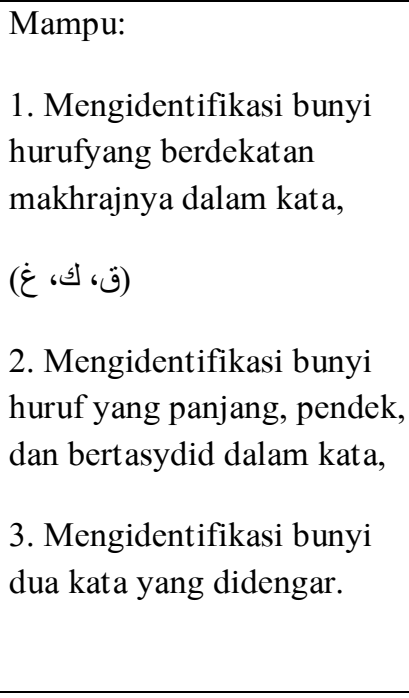 \\
\hline 5 & الدر اسة & $\begin{array}{l}\text { Mampu: } \\
\text { 1. Mengetahui arti } \\
\text { kosakata Arab tentang } \\
\text { ad-dirāsah. } \\
\text { 2. mengetahui kosakata } \\
\text { tentang bangun dan } \\
\text { bentuk } \\
\text { 3. mengetahui kosakata } \\
\text { tentang warna }\end{array}$ & $\begin{array}{l}\text { Mampu: } \\
\text { 1. Menggunakan kata } \\
\text { tanya هيف، أين، متى، } 5 \\
\text { كي، } \\
\text { 2. Menggunakan kata } \\
\text { ganti ه dan } \\
\text { 3. menggunakan kata } \\
\text { perintah } \\
\text { 4. menggunakan kata } \\
\text { larangan }\end{array}$ & $\begin{array}{l}\text { Mampu: } \\
\text { 1. Mengidentifikasi bunyi } \\
\text { القمرية والثمسية } \\
\text { kalimat sederhana yang } \\
\text { didengar. } \\
\text { 3.Memahami perintah dan } \\
\text { larangan yang didengar }\end{array}$ \\
\hline 6 & الهو ايات & $\begin{array}{l}\text { Mampu: } \\
\text { 1. Mengetahui arti } \\
\text { kosakata Arab tentang }\end{array}$ & $\begin{array}{l}\text { Mampu: } \\
\text { 1. Menggunakan } \\
\text { susunan fiim }\end{array}$ & $\begin{array}{l}\text { Mampu: } \\
\text { 1. Memahami percakapan } \\
\text { singkat yang didengar. }\end{array}$ \\
\hline
\end{tabular}


Arabi : Journal of Arabic Studies

\begin{tabular}{|c|c|c|c|c|}
\hline & & $\begin{array}{l}\text { al-hiwäyät. } \\
\text { 2. Mengetahui kosakata } \\
\text { tentang warna }\end{array}$ & $\begin{array}{l}\text { mudhari’ mutaadi } \\
\text { dan maf'ul bih } \\
\text { 2. Menggunakan kata } \\
\text { tanya مل، ماذا، كم، مبتدأ مؤخر Menggunakan } \\
\text { 3. Mengan } \\
\text { susunan } \\
\text { untuk menyebutkan } \\
\text { dan menjawab } \\
\text { pertanyaan tentang } \\
\text { hiwayah } \\
\text { 4. Menggunakan tarkib } \\
\text { adad-ma'dud } \\
\text { nominal } \\
\end{array}$ & $\begin{array}{l}\text { 2. Memahami teks } \\
\text { sederhana yang didengar. }\end{array}$ \\
\hline 7 & العمل & $\begin{array}{l}\text { Mampu: } \\
\text { 1. Mengetahui arti kosa } \\
\text { kata Arab tentang al } \\
\text { amal. } \\
\text { 2. Mencocokkan kosa } \\
\text { kata dengan gambar } \\
\text { tentang profesi dan } \\
\text { perlengkapannya } \\
\text { 3. mengelompokkan } \\
\text { kata }\end{array}$ & $\begin{array}{l}\text { Mampu: } \\
\text { 1. Menggunakan huruf } \\
\text { سو dalam kalimat } \\
\text { sederhana } \\
\text { 2. Menggunakan tarkib } \\
\text { أكون dan khabarnya }\end{array}$ & $\begin{array}{l}\text { Mampu: } \\
\text { 1. Memahami percakapan } \\
\text { yang didengar. } \\
\text { 2. Memahami paragraf } \\
\text { sederhana yang didengar. }\end{array}$ \\
\hline 8 & الرحلة & $\begin{array}{l}\text { Mampu: } \\
\text { 1. Mengetahui arti } \\
\text { kosakata Arab tentang } \\
\text { al-rihlah } 2 \text {. } \\
\text { mengelompokkan kata } \\
\text { 3. Menunjukkan } \\
\text { mufrad, mutsanna, dan } \\
\text { jamak }\end{array}$ & $\begin{array}{l}\text { Mampu: } \\
\text { 1. Menggunakan } \\
\text { ungkapan tentang } \\
\text { zharf makān, } \\
\text { 2. Menggunakan } \\
\text { bilangan nominal 1- } \\
12 \\
\text { 3. Menggunakan } \\
\text { bilangan ordinal 1- } \\
12\end{array}$ & $\begin{array}{l}\text { Mampu: } \\
\text { 1. Memahami percakapan } \\
\text { yang didengar, } \\
\text { 2. Memahami paragraf } \\
\text { yang didengar, }\end{array}$ \\
\hline
\end{tabular}

Tabel 2: Capaian Hasil Belajar Kalām, Qira'āh, dan Kitābah

\begin{tabular}{|c|c|c|c|c|}
\hline \multirow{2}{*}{ Unit } & \multirow{2}{*}{ Judul } & \multicolumn{3}{|c|}{ Capaian Hasil Belajar } \\
\hline & & Kalam & Qira'ah & Kitabah \\
\hline 1 & تعارف & 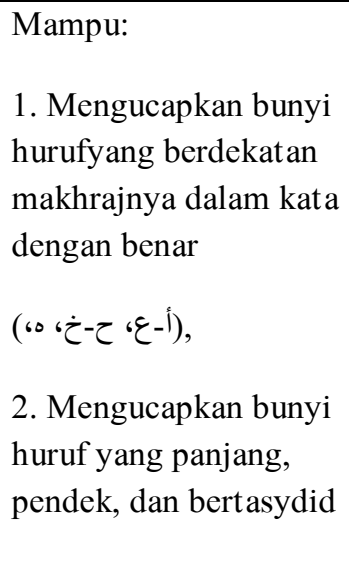 & $\begin{array}{l}\text { Mampu: } \\
\text { 1. Membaca kalimat } \\
\text { sederhana dengan } \\
\text { benar, tentang ta'äruf } \\
\text { 2. Mengetahui arti kata } \\
\text { dalam kalimat } \\
\text { sederhana, tentang } \\
\text { ta'āruf } \\
\text { 3. Memahami kalimat } \\
\text { sederhana tentang }\end{array}$ & 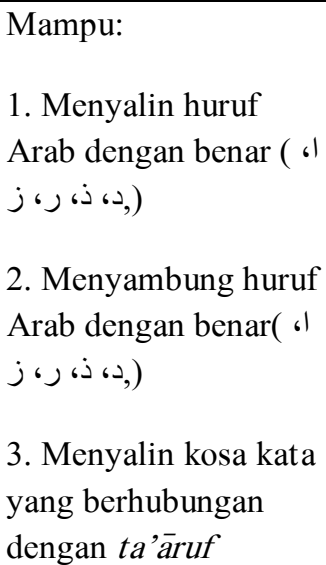 \\
\hline
\end{tabular}




\begin{tabular}{|c|c|c|c|c|}
\hline & & $\begin{array}{l}\text { dalam kata dengan benar, } \\
\text { 3. Mampu } \\
\text { memperkenalkan diri } \\
\text { secara sederhana. }\end{array}$ & ta'āruf & berharokat \\
\hline 2 & الأسرة & 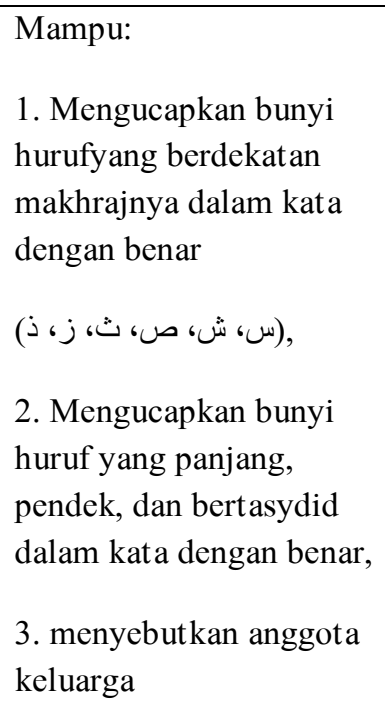 & $\begin{array}{l}\text { Mampu: } \\
\text { 1. Membaca kalimat } \\
\text { sederhana dengan } \\
\text { benar, tenang usrah } \\
\text { 2. Mengetahui arti kata } \\
\text { dalam kalimat } \\
\text { sederhana, tentang } \\
\text { usrah } \\
\text { 3. Memahami kalimat } \\
\text { sederhana tentang usrah }\end{array}$ & 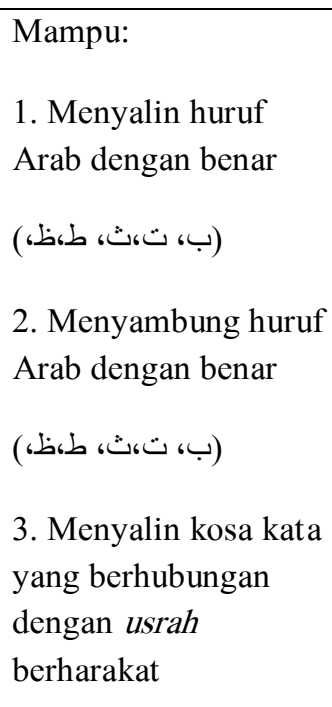 \\
\hline 3 & السكن & 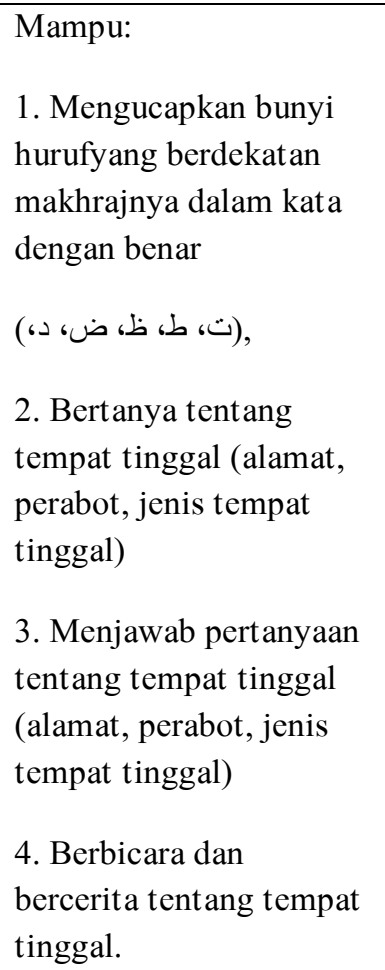 & $\begin{array}{l}\text { Mampu: } \\
\text { 1. Membaca kalimat } \\
\text { sederhana dengan } \\
\text { lancar sesuai dengan } \\
\text { intonasi. } \\
\text { 2. Memahami kalimat } \\
\text { sederhana tentang } \\
\text { tempat tinggal. }\end{array}$ & 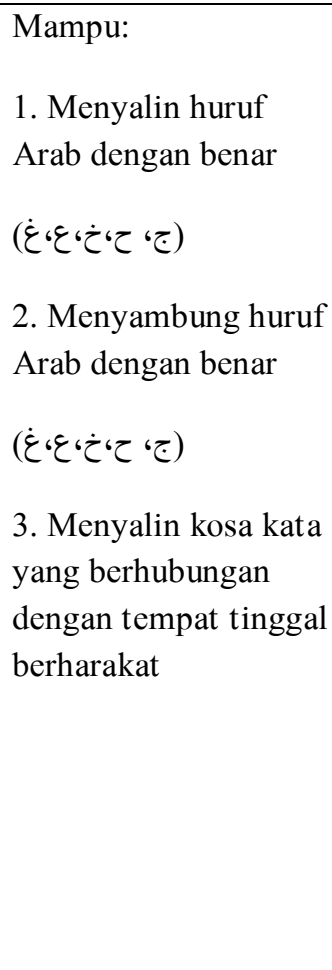 \\
\hline 4 & الالنشطة & $\begin{array}{l}\text { Mampu: } \\
\text { 1. Mengucapkan kosakata } \\
\text { yang mengandung } \\
\text { huruf yang berdekatan } \\
\text { makhrajnya } \\
\text { (ق) (ق) })\end{array}$ & $\begin{array}{l}\text { Mampu: } \\
\text { 1. Membaca teks } \\
\text { sederhana dengan } \\
\text { lancar tentang } \\
\text { kegiatan sehari-hari. } \\
\text { 2. Mengetahui arti teks } \\
\text { sederhana tentang }\end{array}$ & $\begin{array}{l}\text { Mampu: } \\
\text { 1. Menyalin huruf } \\
\text { Arab dengan benar } \\
\text { (س،ش،ص،ض(ض) }\end{array}$ \\
\hline
\end{tabular}


Arabi : Journal of Arabic Studies

\begin{tabular}{|c|c|c|c|c|}
\hline & & $\begin{array}{l}\text { 2. Mendeskripsikan } \\
\text { gambar dalam kalimat } \\
\text { sederhana } \\
\text { 3. Mempraktekkan } \\
\text { percakapan singkat } \\
\text { tentang kegiatan } \\
\text { sehari-hari. } \\
\text { 4. Mampu bercerita } \\
\text { tentang kegiatan } \\
\text { sehari-hari dengan } \\
\text { sederhana. }\end{array}$ & $\begin{array}{l}\text { kegiatan sehari-hari, } \\
\text { 3. Memahami teks } \\
\text { sederhana tentang } \\
\text { kegiatan sehari-hari. }\end{array}$ & 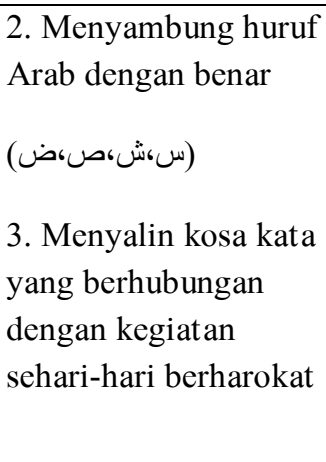 \\
\hline 5 & الدر اسة & $\begin{array}{l}\text { Mampu: } \\
\text { 1. menyebutkan istilah } \\
\text { yang berhubungan } \\
\text { dengan kampus } \\
\text { 2. mempraktekkan } \\
\text { percakapan singkat } \\
\text { tentang studi dengan } \\
\text { sederhana } \\
\text { 3. Mampu menceritakan } \\
\text { kegiatan studi dengan } \\
\text { sederhana. }\end{array}$ & $\begin{array}{l}\text { Mampu: } \\
\text { 1. Membaca teks } \\
\text { sederhana dengan lancar } \\
\text { tentang studi. } \\
\text { 2. Mengetahui arti teks } \\
\text { sederhana tentang studi, } \\
\text { 3. Memahami teks } \\
\text { sederhana tentang studi. }\end{array}$ & 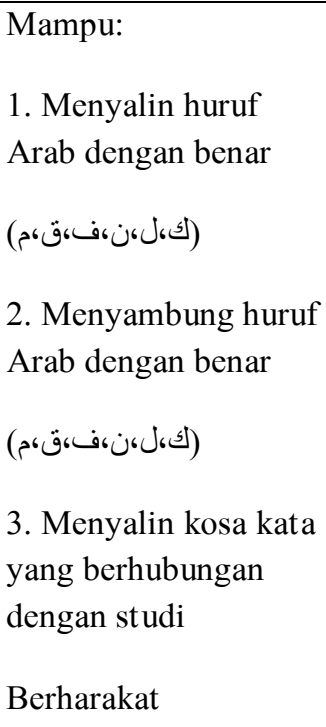 \\
\hline 6 & الهو ايات & $\begin{array}{l}\text { Mampu: } \\
\text { 1. melakukan tanya } \\
\text { jawab tentang hiwayat } \\
\text { 2. Mendeskripsikan } \\
\text { gambar dalam 3-5 kata } \\
\text { 3. menceritakan hobi } \\
\text { sendiri dengan sederhana } \\
\text { 4. menceritakan hobi } \\
\text { orang lain dengan } \\
\text { sederhana }\end{array}$ & $\begin{array}{l}\text { Mampu: } \\
\text { 1. Membaca teks } \\
\text { sederhana dengan lancar } \\
\text { tentang hobi } \\
\text { 2. Mengetahui arti teks } \\
\text { sederhana tentang hobi, } \\
\text { 3. Memahami teks } \\
\text { sederhana tentang hobi. }\end{array}$ & $\begin{array}{l}\text { Mampu: } \\
\text { 1.Menyalin huruf } \\
\text { Arab dengan benar } \\
\text { (ى،:ق،ه) } \\
\text { 2. Menyambung huruf } \\
\text { Arab dengan benar } \\
\text { (ى،:ö،o) } \\
\text { 3. Menyalin kosakata } \\
\text { yang berhubungan } \\
\text { dengan hobi } \\
\text { Berharakat }\end{array}$ \\
\hline 7 & العمل & $\begin{array}{l}\text { Mampu: } \\
\text { 1. Mempraktekkan } \\
\text { percakapan tentang } \\
\text { pekerjaan } \\
\text { 2. Mendeskripsikan } \\
\text { gambar dalam 4-6 kata } \\
\text { 3. Bercerita tentang cita- } \\
\text { cita pekerjaan dalam } \\
\text { kalimat sederhana }\end{array}$ & $\begin{array}{l}\text { Mampu: } \\
\text { 1. Membaca teks } \\
\text { sederhana dengan lancar } \\
\text { tentang al-'amal. } \\
\text { 2. Mengetahui arti teks } \\
\text { sederhana tentang al- }\end{array}$ & $\begin{array}{l}\text { Mampu: } \\
\text { 1. Merangkai huruf } \\
\text { menjadi kata } \\
\text { 2.Menulis kosakata } \\
\text { yang diketahui } \\
\text { 3. Menyusun kata }\end{array}$ \\
\hline
\end{tabular}




\begin{tabular}{|c|c|c|c|c|}
\hline & & & $\begin{array}{l}\text { amal, } \\
\text { 3. Memahami teks } \\
\text { sederhana tentang al- } \\
\text { amal. }\end{array}$ & menjadi kalimat \\
\hline 8 & الرحلة & $\begin{array}{l}\text { Mampu: } \\
\text { 1. Mengucapkan ta'birät } \\
\text { terkait ar-rihlah } \\
\text { 2. Mendeskripsikan } \\
\text { gambar tentang ar-rihlah } \\
\text { dengan 7-10 kata }\end{array}$ & $\begin{array}{l}\text { Mampu: } \\
\text { 1. Membaca teks } \\
\text { sederhana dengan lancar } \\
\text { tentang rihlah. } \\
\text { 2. Mengetahui arti teks } \\
\text { sederhana tentang } \\
\text { rihlah, } \\
\text { 3. Memahami teks } \\
\text { sederhana tentang } \\
\text { rihlah. }\end{array}$ & $\begin{array}{l}\text { Mampu: } \\
\text { 1. Merangkai huruf } \\
\text { menjadi kata } \\
\text { 2.Menulis kosa kata } \\
\text { yang diketahui } \\
\text { 3. Menyusun kata } \\
\text { menjadi kalimat }\end{array}$ \\
\hline
\end{tabular}

Tabel satu dan dua di atas menjelaskan capaian hasil belajar pada tiap-tiap materi. Capaian hasil belajar tersebut sifatnya wajib untuk dicapai oleh setiap mahasiswa yang menggunakan buku ajar ALH.

Adapun waktu yang disediakan untuk mengajarkan ALH adalah 120 pertemuan efektif. Tiap pertemuan membutuhkan waktu 90 menit. Jika pembelajarannya menggunakan pembelajaran intensif seperti yang dilakukan Pusat Pengembangan Bahasa Arab UIN Maulana Malik Ibrahim Malang, maka waktu yang dibutuhkan adalah dua bulan atau delapan minggu. Proses pembelajaran dilaksanakan setiap hari Senin sampai Jumat; lima hari dalam seminggu. Setiap hari terdiri dari dua kali pertemuan, tiap pertemuan 90 menit efektif.

Dalam buku ALH, evaluasi dilakukan setiap setelah empat unit atau setiap bulan sekali (ikhtibär syahrï/tes bulanan), tujuan utamannya adalah untuk mengetahui tingkat kemampuan mahasiswa dan memantau perkembangan kemampuannya.

\section{Efektivitas Penerapan Buku Ajar Al-‘Arabiyyah Lil Hayah}

Pengembangan bahan ajar bahasa Arab telah dilakukan pada buku ajar ALH melalui uji coba pakar dan juga uji coba lapangan kepada para mahasiswa baik di level Mutaqaddim (Advance), Mutawassith (Intermediate), dan Mubtadi (Elementary). Berdasarkan masukan-masukan para pakar, maka telah dilakukan beberapa perbaikan untuk menyempurkan keutuhan produk buku ajar ini. Oleh karena itu, di bawah ini dipaparkan hasil uji coba lapangan untuk diketahui efektifitas penggunaan bahan ajar Bahasa Arab yang telah dikembangkan dengan sampel yang tersaji berikut ini:

Berdasarkan hasil analisis data lapangan, maka dapat disimpulkan bahwa tingkat signifikansi penggunaan buku ajar bahasa Arab berbasis konstruktivisme sangat signifikan dan berpengaruh terhadap peningkatan hasil belajar selama proses penggunaan buku tersebut. Berdasarkan hasil analisis data melalui SPSS diperoleh keterangan bahwa rata-rata nilai pre-test mahasiswa adalah 39,53, sementara rata-rata nilai kelas post-test adalah 82,5 yang berarti terdapat peningkatan hasil belajar yang signifikan sekitar 42,97 poin. Sedangkan standar deviasi pre-test sebanyak 24,48 dan post-test 6,77 yang menunjukkan keberagaman secara signifikan kemampuan bahasa Arab 
mahasiswa sebelum diterapkan pembelajaran dengan produk buku ajar ALH, sedangkan proses pembelajaran setelah diterapkan produk buku ajar dinilai efektif dengan standar deviasi sebesar 6,77 yang berarti hasil post-test relatif merata dengan selisih yang tidak terlalu berbeda jauh. Dengan demikian dapat disimpulkan bahwa terdapat peningkatan signifikan kemampuan mahasiswa antara sebelum dan sesudah pembelajaran.

Adapun hasil uji korelasi menunjukkan bahwa korelasi antara dua variabel adalah sebesar 0,911 dengan sig sebesar 0,000. Hal ini menunjukkan bahwa korelasi antara dua rata-rata kemampuan mahasiswa bahasa Arab keseluruhan sebelum menggunakan produk bahan ajar bahasa Arab dengan sesudah menggunakannya adalah sempurna dan signifikan. Dengan demikian dapat diartikan bahwa peningkatan hasil belajar setelah menggunakan produk buku ajar sangat signifikan, sempurna, dan berpengaruh pada peningkatan kompetensi mahasiswa dalam penguasaan bahasa Arab secara keseluruhan.

Sedangkan hasil uji Hipotesis, maka nilai t hitung hasil belajar mahasiswa sebelum dan sesudah menggunakan produk buku ajar secara adalah sebesar $-12,701$ dengan sig 0,000. Dikarenakan sig lebih kecil dari 0,05 $(0,00-0,05)$ maka dapat disimpulkan bahwa $\mathrm{H}_{1}$ diterima dan $\mathrm{H}_{\mathrm{o}}$ ditolak, artinya rata-rata nilai keseluruhan mahasiswa sebelum dan sesudah menggunakan produk bahan ajar bahasa Arab adalah tidak sama (berbeda). Dengan demikian dapat dinyatakan bahwa penggunaan produk buku ajar bahasa Arab secara umum mempengaruhi hasil belajar dan peningkatan kemampuan mahasiswa Program Khusus Perkuliahan Bahasa Arab. Rata-rata tersebut mengalami perbedaan yang signifikan di mana sebelum diterapkan produk buku ajar, kemampuan bahasa Arab mahasiswa berada pada 39,53. Sementara setelah diterapkan produk buku ajar, ratarata hasil belajar mencapai 82,50 yang secara umum mengalami peningkatan secara bersama-sama dan merata di semua kemampuan mahasiswa.

\section{Simpulan}

Adapun hasil pembahasan penelitian yang telah dilakukan tentang pengembangan bahan ajar bahasa Arab berbasis teori belajar konstruktivisme untuk mahasiswa PTKIN berdasarkan masukan dan hasil ujicoba lapangan, diperolah kesimpulan sebagai berikut:

1. Hasil ujicoba terhadap komponen-komponen buku ajar ALH menunjukkan bahwa: ahli isi bahasa Arab menilai buku bahasa Arab ALH sangat baik dan layak, sedangkan ahli desain pembelajaran memberikan penilaian bahwa sebagian besar komponen buku ajar ALH sudah sangat layak. Subyek uji coba perorangan menilai bahwa sebagian besar komponen bahan pembelajaran sudah sangat baik. Dosen bahasa Arab menilai sebagian besar komponen buku ajar sudah sangat layak dan subyek uji coba lapangan juga menilainya sangat baik.

2. Produk akhir pengembangan ini adalah berupa buku ajar bahasa Arab al-'Arabiyah Lil Hayah (ALH). Buku ajar yang dikembangkan ini dirancang dengan memuat komponen-komponen yang memudahkan mahasiswa belajar dengan menggunakan teori belajar kontruktivisme yang menekankan pada proses belajar, mendorong peserta didik untuk berpartisipasi aktif dalam dialog atau diskusi dengan peserta didik lain dan guru, melibatkan peserta didik dalam situasi dunia nyata, menekankan pentingnya konteks dalam belajar, dan memberikan kesempatan kepada peserta didik untuk membangung pengetahuan dan pemahaman baru yang didasarkan pada pengalaman nyata.

3. Berdasarkan perhitungan dengan teknik analisis uji-t, buku ALH efektif untuk meningkatkan kemampuan bahasa Arab mahasiswa PKPBA UIN Maulana Malik Ibrahim Malang. Dengan demikian bahwa terdapat perbedaan yang signifikan antara perolehan belajar mahasiswa sebelum dan sesudah dilakukan ujicoba. Hal ini berarti bahwa pembelajaran dengan menggunakan produk yang dikembangkan efektif dalam rangka peningkatan perolehan belajar mahasiswa, sehingga produk tersebut layak digunakan untuk mahasiswa di lingkungan PTKIN.[] 


\section{Arabi : Journal of Arabic Studies}

\section{Daftar Rujukan}

A'dho Haeah al-Tadris bi Jamiah al-Quds al-Maftuhah. 2000. Intaj al-Mawad al-Ta'limiyah li Baramij al-Ta'lim an Bu'd. al-Magrib: ISESCO.

AECT. 2000. Definisi Teknologi Pendidikan: Satuan Tugas Definisi dan Terminologi AECT. Terjemahan Miarso, Y.H. Jakarta: Rajawali.

Buchori, Achmad., \& Rina Dwi Setyawati. 2015. "Development Learning Model Of Character Education Through E-Comic In Elementary School", International Journal of Education and Research, Vol. 3, No. 9.

Cakir, Mustafa. 2008. "Constructivist Approaches to Learning in Science and Their Implications for Science Pedagogy: A Literature Review”, International Journal of Environmental \& Science Education, Vol. 3, No. 4.

Degeng, I N.S. 1991. Strategi Pembelajaran: Mengorganisasi Isi dengan Model Elaborasi. Malang: IKIP Malang dan IPTPI.

Dick, W., \& Carey L. 1991. The Systematic Design of Instruction. Glenview: Scott, Foresman and Company.

Gursesa, Ahmet., Seher Demiraya., Cetin Doğar. 2015. ”A Design Practice For Interactive-Direct Teaching Based On Constructivist Learning: Dissolution And Solutions", Procedia - Social and Behavioral Sciences, Vol. 191.

Jia, Qiong. 2010. “A Brief Study on the Implication of Constructivism Teaching Theory on Classroom Teaching Reform in Basic Education”, International Education Studies, Vol. 3, No. 2.

Mills, Jane., Ann Bonner., and Karen Francis. 2006. "The Development of Constructivist Grounded Theory", Ijom; International Journal of Qualitative Methods, Vol. 5, No. 1.

Musthofa, Intishar Ghazi. 2016. "Mumarasat at-Ta'allum al-Binai Lada Muallim at-Tarbiyah alIslamiyah wa 'Alaqatuha bi ba'dhi al-Mutaghayyirat", al-Majallah al-Urduniyyah fi al-Ulum al-Tarbawiyyah, Vol. 12, No. 3.

Nasution, Sahkholid., dan Zulheddi. 2018. "Pengembangan Model Pembelajaran Bahasa Arab Berbasis Teori Konstruktivisme di Perguruan Tinggi", Arabi : Journal of Arabic Studies, Vol. 3, No. 2.

Scoffham, Stephen. 2018. "Global Learning: A Catalyst for Curriculum Change”, International Journal of Development Education and Global Learning, Vol. 10, No. 2.

Suparman, A. 1994. Pokok - Pokok Panduan Penulisan Bahan Ajar di Perguruan Tinggi. Jakarta: Pusat Antar Universitas untuk Peningkatan dan Pengembangan Aktivitas Instruksional Ditjen Dikti Departemen Pendidikan dan Kebudayaan.

Widayat, Prabowo Adi. 2017. "Inovasi Kurikulum Bahasa Arab Madrasah Aliyah Berbasis Konstruktivisme”, Jurnal an-Nabighoh, Vol. 19, No. 1. 